\title{
Refinement of the Crystal Structure of Triclinic Magnesium Pyroborate
}

\author{
Stanley Block, Gordon Burley, Alvin Perloff, and Robert D. Mason, Jr.
}

\begin{abstract}
The triclinic modification of $\mathrm{Mg}_{2} \mathrm{~B}_{2} \mathrm{O}_{5}$ was classified as a member of an isostructural series which also includes $\mathrm{Mn}_{2} \mathrm{~B}_{2} \mathrm{O}_{5}, \mathrm{Fe}_{2} \mathrm{~B}_{2} \mathrm{O}_{5}$, and $\mathrm{Co}_{2} \mathrm{~B}_{2} \mathrm{O}_{5}$. The crystal structure was refined by the use of successive Fourier projections and a least-squares refinement program on an electronic computer. The structure of $\mathrm{Mg}_{2} \mathrm{~B}_{2} \mathrm{O}_{5}$ consists of $\mathrm{B}_{2} \mathrm{O}_{5}{ }^{-4}$ groups and $\mathrm{Mg}^{+2}$ ions. Each magnesium atom is surrounded octahedrally by six oxygen atoms, forming an extended sheet of octahedra. The pyroborate groups share corners with octahedra in the sheets and thus link them. Each boron atom is in planar triangular coordination with three oxygen atoms. The pyroborate group has two such triangles with one shared oxygen. The angle between the planes formed by the triangles is $16^{\circ}$. The average boron-to-oxygen distance is $1.38 \mathrm{~A}$.
\end{abstract}

\section{Introduction}

As part of an over-all study of the crystal chemistry of borates it was decided to study the crystal structure of magnesium borate. The American Society for Testing Materials file [1] ${ }^{1}$ indicates that $\mathrm{MgB}_{2} \mathrm{O}_{4}$ is isomorphous with the corresponding manganous and ferrous compounds. This series would be an excellent choice for study because the Mn or Fe could be used to determine the approximate structure by heavy atom techniques. The $\mathrm{Mg}$ compound would then be used to determine the bond distances and angles accurately.

Single crystal work on the magnesium compound was undertaken and the cell constants were determined. These indicated that the magnesium compound is isomorphous with $2 \mathrm{CoO} \cdot \mathrm{B}_{2} \mathrm{O}_{3}$ [2]. In addition, the phase diagram of the system $\mathrm{MgO}-\mathrm{B}_{2} \mathrm{O}_{3}$ [3] shows that the solid crystallizing from a melt of composition $\mathrm{MgO} \cdot \mathrm{B}_{2} \mathrm{O}_{3}$ will have the composition $2 \mathrm{MgO} \cdot \mathrm{B}_{2} \mathrm{O}_{3}$ since $\mathrm{MgO} \cdot \mathrm{B}_{2} \mathrm{O}_{3}$ does not exist in equilibrium with the liquid. A monoclinic phase and a triclinic phase of manganous pyroborate were found. The ferrous pyroborate and the triclinic phase of manganous pyroborate were also proven isomorphous with the cobalt and magnesium pyroborates, so that the correct formula for the series is not $\mathrm{MB}_{2} \mathrm{O}_{4}$ but $\mathrm{M}_{2} \mathrm{~B}_{2} \mathrm{O}_{5}$, where $\mathrm{M}$ is $\mathrm{Mg}^{+2}, \mathrm{Fe}^{+2}$, $\mathrm{Mn}^{+2}$, or $\mathrm{Co}^{+2}$.

Pyroborate compounds have also been investigated by Takeuchi [4], who determined the crystal structure of suanite, which is the monoclinic form of magnesium pyroborate. He also suggested parameters for the triclinic form. These parameters differed slightly from those determined by Berger for $\mathrm{Co}_{2} \mathrm{~B}_{2} \mathrm{O}_{5}[2]$. It was deemed desirable to refine the structural parameters of the $\mathrm{Mg}_{2} \mathrm{~B}_{2} \mathrm{O}_{5}$ in order to define the $\mathrm{B}_{2} \mathrm{O}_{5}^{-4}$ configuration accurately. In the X-ray scattering process the form factor is proportional to the atomic number. Thus the $\mathrm{Mg}: \mathrm{B}$ scattering ratio presented the most favorable case in the isomorphous series for elucidating the pyroborate configuration.

\footnotetext{
${ }^{1}$ Figures in brackets indicate the literature references at the end of this paper.
}

\section{Experimental Techniques}

Single crystals of $\mathrm{Fe}_{2} \mathrm{~B}_{2} \mathrm{O}_{5}$ and both phases of $\mathrm{Mn}_{2} \mathrm{~B}_{2} \mathrm{O}_{5}$ were obtained by crystallization from the melt and cell constants obtained on a Buerger precession camera. The single crystals of $\mathrm{Mg}_{2} \mathrm{~B}_{2} \mathrm{O}_{5}$ used were either taken directly from a devitrified glass or recrystallized from it. Data was obtained on a Nonius integrating Weissenberg camera using $\mathrm{Cu} \mathrm{K}_{\alpha}$ radiation. Zero layers and $b$-axis upper layers were taken. Integrated intensities were read directly on a densitometer comparator. Lorentz-polarization corrections were applied according to the method given by Lu [5].

\section{Structure}

\subsection{Space Group and Cell Constants}

$\mathrm{Mg}_{2} \mathrm{~B}_{2} \mathrm{O}_{5}$ crystallizes in the triclinic system, space group $\mathrm{P} \overline{1}$. The cell dimensions were obtained from single-crystal precession and Weissenberg data.

The cell constants for the four members of the isomorphous series are given in table 1 . For the $\mathrm{Mg}_{2} \mathrm{~B}_{2} \mathrm{O}_{5}$ the cell volume is $172.0 \mathrm{~A}^{3}$ and the calculated density for two formula units per cell is $2.90 \mathrm{~g} / \mathrm{cm}^{3}$ (observed $2.92 \mathrm{~g} / \mathrm{cm}^{3}$ ).

TABLE 1. Cell constants for triclinic phases

\begin{tabular}{|c|c|c|c|c|c|c|}
\hline & $a$ & $b$ & $c$ & $\alpha$ & $\beta$ & $\gamma$ \\
\hline $\begin{array}{l}\mathrm{Mg}_{2} \mathrm{~B}_{2} \mathrm{O}_{5} \\
\mathrm{Mn}_{2} \mathrm{~B}_{2} \mathrm{O}_{5} \\
\mathrm{Fe}_{2} \mathrm{~B}_{2} \mathrm{O}_{5} \\
\mathrm{Co}_{2} \mathrm{~B}_{2} \mathrm{O}_{5}\end{array}$ & $\begin{array}{l}6.18_{7} \\
\text { 6. } 26_{6} \\
6.18_{2} \\
5.94\end{array}$ & $\begin{array}{l}9.21_{9} \\
9.57_{5} \\
9.40_{4} \\
8.95\end{array}$ & $\begin{array}{l}\text { 3. } 11_{9} \\
3.27_{1} \\
3.254 \\
3.16\end{array}$ & $\begin{array}{l}90^{\circ} 24^{\prime} \\
90^{\circ} 34^{\prime} \\
90^{\circ} 37^{\prime} \\
91^{\circ} 0^{\prime}\end{array}$ & $\begin{array}{l}92^{\circ} 08^{\prime} \\
91^{\circ} 53^{\prime} \\
91^{\circ} 29^{\prime} \\
92^{\circ} 0^{\prime}\end{array}$ & $\begin{array}{l}104^{\circ} 19^{\prime} \\
104^{\circ} 55^{\prime} \\
104^{\circ} 10^{\prime} \\
103^{\circ} 54^{\prime}\end{array}$ \\
\hline \multicolumn{7}{|c|}{ Monoclinic } \\
\hline $\begin{array}{l}\mathrm{Mn}_{2} \mathrm{~B}_{2} \mathrm{O}_{5} \ldots \\
\quad \mathrm{P} 2_{1} / \mathrm{c}\end{array}$ & 3. $25_{2}$ & 9.537 & $9.90_{5}$ & - - & $110^{\circ} 00^{\prime}$ & - \\
\hline
\end{tabular}

\subsection{Structure Determination}

The only well resolved projection of the electron density for this structure was on the plane containing the $a$ and $b$ axes, i.e., on (001). Preliminary refine- 
ment was carried out by use of successive Fourier projections. The signs for the structure factors were derived from the trial structure analogous to the $\mathrm{Co}_{2} \mathrm{~B}_{2} \mathrm{O}_{5}$, with $\mathrm{Mg}$ replacing the Co. The final Fourier projection is shown in figure 1. At this stage the reliability factor $R$, defined as

$$
R=\Sigma|| \mathrm{F}_{0}|-| \mathrm{F}_{\mathrm{c}}|| / \Sigma\left|\mathrm{F}_{0}\right|
$$

was 0.125 for the 99 observed $h k 0$ nonzero reflections. The structure was in good agreement with the corresponding Patterson projection (fig. 2). It is essentially the same structure as proposed by Takeuchi, with the origin shifted by $\left(\frac{1}{2}, \frac{1}{2}, 0\right)$.

The final stages of refinement consisted of a leastsquares reduction of the data, using the electronic computer and the NYXRIA routine written by Sayre [6] and revised by Vand [7]. The zero and 4 upper levels of Weissenberg data around the $b$ axis

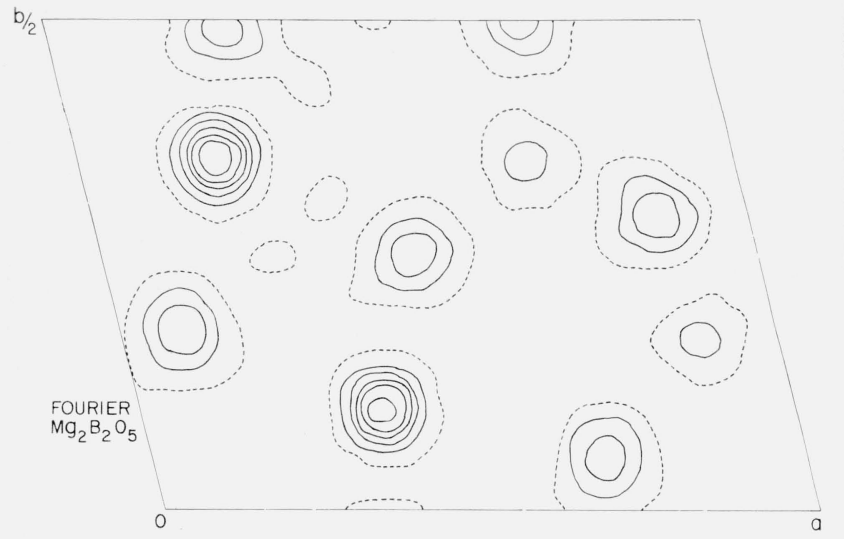

Figure 1. Fourier projection of $\mathrm{Mg}_{2} \mathrm{~B}_{2} \mathrm{O}_{5}$ on the (001) plane.

In order of increasing number of contour lines the atoms are B, O, and $\mathrm{Mg}$. Half the unit cell is shown for the centrosymmetric space group.

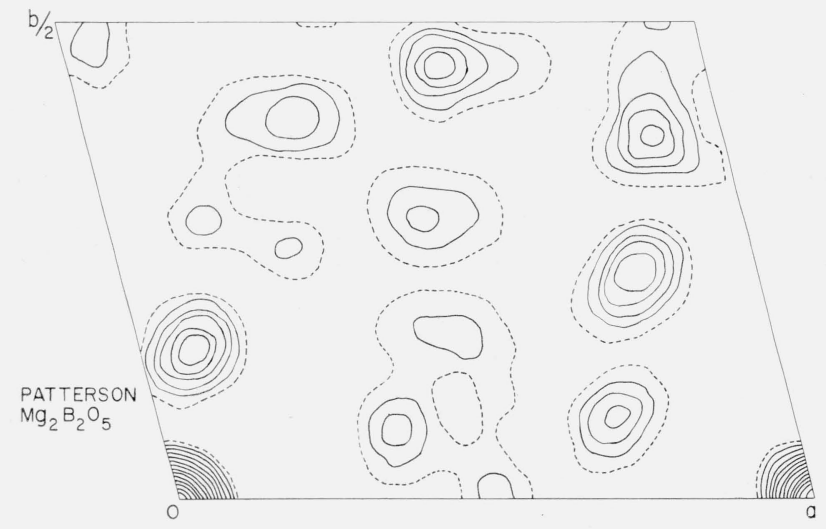

Figure 2. Patterson projection of $\mathrm{Mg}_{2} \mathrm{~B}_{2} \mathrm{O}_{5}$ on the (001) plane. were used. The final $R$ value for the $\mathrm{Mg}_{2} \mathrm{~B}_{2} \mathrm{O}_{5}$ structure is 0.123 , using 331 nonzero independent reflections. An isotropic temperature factor for each atom was used. The atomic coordinates and temperature factors are listed in table 2. Measured and calculated structure factors are given in table 3.

TABLE 2. Atomic coordinates of triclinic $\mathrm{Mg}_{2} \mathrm{~B}_{2} \mathrm{O}_{5}$

\begin{tabular}{|c|c|c|c|c|}
\hline & $x / a$ & $y / b$ & $z / c$ & $B$ \\
\hline $\begin{array}{l}\mathrm{Mg}_{1} \\
\mathrm{Mg}_{2}\end{array}$ & $\begin{array}{r}0.2105 \\
.3724\end{array}$ & $\begin{array}{r}0.3562 \\
.1026\end{array}$ & $\begin{array}{r}0.7264 \\
.2345\end{array}$ & $\begin{array}{l}0.70^{*} \mathrm{~A}^{2} \\
.68\end{array}$ \\
\hline $\begin{array}{l}\mathrm{O}_{1} \\
\mathrm{O}_{2} \\
\mathrm{O}_{3} \\
\mathrm{O}_{4} \\
\mathrm{O}_{5}\end{array}$ & $\begin{array}{l}.6972 \\
.0931 \\
.4782 \\
.8633 \\
.7224\end{array}$ & $\begin{array}{l}.0511 \\
.1784 \\
.2595 \\
.2995 \\
.5077\end{array}$ & $\begin{array}{l}.2631 \\
.2263 \\
.7376 \\
.5604 \\
.7709\end{array}$ & $\begin{array}{l}.89 \\
.89 \\
.79 \\
.97 \\
.78\end{array}$ \\
\hline $\begin{array}{l}\mathrm{B}_{1} \ldots \\
\mathrm{B}_{2}\end{array}$ & $\begin{array}{l}.6836 \\
.8814\end{array}$ & $\begin{array}{l}.3538 \\
.1708\end{array}$ & $\begin{array}{l}.6997 \\
.3392\end{array}$ & $\begin{array}{l}.33 \\
.37\end{array}$ \\
\hline
\end{tabular}

TABLE 3. Calculated and observed structure factors for triclinic $\mathrm{Mg}_{2} \mathrm{~B}_{2} \mathrm{O}_{5}$

$k=0$

\begin{tabular}{|c|c|c|c|c|}
\hline & 0 & +1 & +2 & +3 \\
\hline-7 & & $\begin{array}{c}-1200^{a} \\
191\end{array}$ & & \\
\hline-6 & & & $\begin{array}{r}+23 \\
28\end{array}$ & \\
\hline-5 & & $\begin{array}{r}-85 \\
96\end{array}$ & $\begin{array}{r}-39 \\
39\end{array}$ & $\begin{array}{r}+29 \\
37\end{array}$ \\
\hline-4 & & $\begin{array}{r}+228 \\
268\end{array}$ & $\begin{array}{r}-26 \\
14\end{array}$ & $\begin{array}{r}-77 \\
87\end{array}$ \\
\hline-3 & & $\begin{array}{r}+295 \\
339\end{array}$ & $\begin{array}{r}-68 \\
58\end{array}$ & $\begin{array}{r}-120 \\
124\end{array}$ \\
\hline-2 & & $\begin{array}{r}-91 \\
87\end{array}$ & $\begin{array}{r}+140 \\
140\end{array}$ & $\begin{array}{r}+76 \\
83\end{array}$ \\
\hline-1 & & $\begin{array}{r}-22 \\
21\end{array}$ & $\begin{array}{r}+205 \\
249\end{array}$ & $\begin{array}{r}+16 \\
14\end{array}$ \\
\hline 0 & & $\begin{array}{r}-156 \\
214\end{array}$ & $\begin{array}{r}-532 \\
670\end{array}$ & $\begin{array}{r}+33 \\
39\end{array}$ \\
\hline+1 & $\begin{array}{r}-63 \\
75\end{array}$ & $\begin{array}{r}-134 \\
170\end{array}$ & $\begin{array}{r}+74 \\
87\end{array}$ & \\
\hline+2 & $\begin{array}{r}-259 \\
285\end{array}$ & $\begin{array}{r}+160 \\
190\end{array}$ & $\begin{array}{r}+139 \\
144\end{array}$ & $\begin{array}{r}-140 \\
161\end{array}$ \\
\hline+3 & $\begin{array}{r}-33 \\
40\end{array}$ & $\begin{array}{r}+110 \\
110\end{array}$ & $\begin{array}{r}-70 \\
68\end{array}$ & $\begin{array}{r}+63 \\
69\end{array}$ \\
\hline+4 & $\begin{array}{r}-85 \\
86\end{array}$ & $\begin{array}{r}-134 \\
131\end{array}$ & & \\
\hline+5 & $\begin{array}{r}-74 \\
71\end{array}$ & $\begin{array}{r}+135 \\
146\end{array}$ & & \\
\hline+6 & $\begin{array}{r}+20 \\
28\end{array}$ & $\begin{array}{r}-40 \\
52\end{array}$ & & \\
\hline+7 & $\begin{array}{r}-57 \\
71\end{array}$ & & & \\
\hline
\end{tabular}

a Numbers with signs are calculated structure factors and numbers without signs are observed values. 
TABLE 3. Calculated and observed structure factors for triclinic $\mathrm{Mg}_{2} \mathrm{~B}_{2} \mathrm{O}_{5}$ - Continued

$k=1$

\begin{tabular}{|c|c|c|c|c|c|c|}
\hline & -2 & -1 & 0 & +1 & +2 & +3 \\
\hline-7 & & & $\begin{array}{r}-35 \\
33\end{array}$ & $\begin{array}{r}-101 \\
102\end{array}$ & & \\
\hline-6 & & $\begin{array}{r}-291 \\
279\end{array}$ & $\begin{array}{r}+163 \\
172\end{array}$ & $\begin{array}{r}+221 \\
222\end{array}$ & $\begin{array}{r}-120 \\
120\end{array}$ & \\
\hline-5 & $\begin{array}{r}+56 \\
44\end{array}$ & $\begin{array}{r}-46 \\
40\end{array}$ & $\begin{array}{r}+68 \\
67\end{array}$ & & & \\
\hline-4 & $\begin{array}{r}+208 \\
161\end{array}$ & $\begin{array}{r}-60 \\
54\end{array}$ & $\begin{array}{r}-312 \\
296\end{array}$ & $\begin{array}{r}+52 \\
48\end{array}$ & $\begin{array}{r}+293 \\
296\end{array}$ & $\begin{array}{r}-102 \\
94\end{array}$ \\
\hline-3 & $\begin{array}{r}-232 \\
189\end{array}$ & $\begin{array}{r}+108 \\
85\end{array}$ & $\begin{array}{r}+213 \\
218\end{array}$ & & $\begin{array}{r}-95 \\
90\end{array}$ & $\begin{array}{r}-54 \\
48\end{array}$ \\
\hline-2 & & $\begin{array}{r}+101 \\
95\end{array}$ & $\begin{array}{r}+79 \\
84\end{array}$ & $\begin{array}{r}+80 \\
95\end{array}$ & $\begin{array}{r}-126 \\
125\end{array}$ & \\
\hline-1 & & $\begin{array}{r}+242 \\
267\end{array}$ & $\begin{array}{r}+3 \\
34\end{array}$ & $\begin{array}{r}-15 \\
30\end{array}$ & $\begin{array}{r}-118 \\
99\end{array}$ & \\
\hline 0 & & & $\begin{array}{r}+27 \\
26\end{array}$ & $\begin{array}{r}+88 \\
91\end{array}$ & $\begin{array}{r}-159 \\
157\end{array}$ & \\
\hline+1 & & $\begin{array}{r}-23 \\
36\end{array}$ & $\begin{array}{r}-173 \\
173\end{array}$ & $\begin{array}{r}-147 \\
173\end{array}$ & $\begin{array}{r}+204 \\
183\end{array}$ & $\begin{array}{r}+97 \\
101\end{array}$ \\
\hline+2 & $\begin{array}{r}-62 \\
61\end{array}$ & & $\begin{array}{r}+227 \\
233\end{array}$ & $\begin{array}{r}-164 \\
169\end{array}$ & & \\
\hline+3 & & $\begin{array}{r}-243 \\
257\end{array}$ & $\begin{array}{r}+128 \\
129\end{array}$ & $\begin{array}{r}-396 \\
424\end{array}$ & $\begin{array}{r}-57 \\
56\end{array}$ & $\begin{array}{r}+166 \\
165\end{array}$ \\
\hline+4 & $\begin{array}{r}+83 \\
72\end{array}$ & $\begin{array}{r}-377 \\
428\end{array}$ & $\begin{array}{r}-93 \\
99\end{array}$ & $\begin{array}{r}+294 \\
319\end{array}$ & $\begin{array}{r}+37 \\
40\end{array}$ & $\begin{array}{r}-127 \\
140\end{array}$ \\
\hline+5 & & $\begin{array}{r}-16 \\
41\end{array}$ & $\begin{array}{r}-107 \\
127\end{array}$ & $\begin{array}{r}+145 \\
157\end{array}$ & $\begin{array}{r}+50 \\
61\end{array}$ & \\
\hline+6 & $\begin{array}{r}+46 \\
41\end{array}$ & $\begin{array}{r}+172 \\
208\end{array}$ & $\begin{array}{r}-139 \\
151\end{array}$ & $\begin{array}{r}-59 \\
64\end{array}$ & $\begin{array}{r}+52 \\
45\end{array}$ & \\
\hline+7 & & & & $\begin{array}{r}+28 \\
28\end{array}$ & & \\
\hline
\end{tabular}

$k=2$

\begin{tabular}{|c|c|c|c|c|c|c|}
\hline & -2 & -1 & 0 & +1 & +2 & +3 \\
\hline-6 & & $\begin{array}{r}+27 \\
26\end{array}$ & $\begin{array}{r}-21 \\
23\end{array}$ & $\begin{array}{r}+52 \\
53\end{array}$ & $\begin{array}{r}-16 \\
20\end{array}$ & \\
\hline-5 & $\begin{array}{r}+113 \\
103\end{array}$ & & $\begin{array}{r}-116 \\
112\end{array}$ & & $\begin{array}{r}+43 \\
38\end{array}$ & $\begin{array}{r}+52 \\
41\end{array}$ \\
\hline-4 & $\begin{array}{r}-85 \\
66\end{array}$ & $\begin{array}{r}-68 \\
48\end{array}$ & $\begin{array}{r}187 \\
172\end{array}$ & $\begin{array}{r}-21 \\
23\end{array}$ & $\begin{array}{r}-57 \\
55\end{array}$ & $\begin{array}{r}+47 \\
37\end{array}$ \\
\hline-3 & $\begin{array}{r}-231 \\
193\end{array}$ & $\begin{array}{r}+8 \\
22\end{array}$ & $\begin{array}{r}+634 \\
600\end{array}$ & $\begin{array}{r}-132 \\
115\end{array}$ & $\begin{array}{r}-357 \\
323\end{array}$ & \\
\hline-2 & & $\begin{array}{r}-109 \\
101\end{array}$ & $\begin{array}{r}-399 \\
332\end{array}$ & $\begin{array}{r}+30 \\
27\end{array}$ & $\begin{array}{r}+232 \\
227\end{array}$ & $\begin{array}{r}-101 \\
98\end{array}$ \\
\hline-1 & & $\begin{array}{r}-21 \\
22\end{array}$ & $\begin{array}{r}-134 \\
107\end{array}$ & $+\begin{array}{r}113 \\
106\end{array}$ & $\begin{array}{r}+128 \\
112\end{array}$ & $\begin{array}{r}-143 \\
132\end{array}$ \\
\hline 0 & & $\begin{array}{r}+134 \\
144\end{array}$ & $\begin{array}{r}-134 \\
107\end{array}$ & $\begin{array}{r}-468 \\
489\end{array}$ & $\begin{array}{r}+35 \\
30\end{array}$ & $\begin{array}{r}+168 \\
175\end{array}$ \\
\hline+1 & $\begin{array}{r}-46 \\
37\end{array}$ & $\begin{array}{r}74 \\
78\end{array}$ & $\begin{array}{r}-120 \\
119\end{array}$ & & $\begin{array}{r}-38 \\
40\end{array}$ & $\begin{array}{r}+85 \\
82\end{array}$ \\
\hline+2 & & $\begin{array}{r}-236 \\
214\end{array}$ & $\begin{array}{r}-99 \\
105\end{array}$ & $\begin{array}{r}+228 \\
194\end{array}$ & $\begin{array}{r}-59 \\
54\end{array}$ & $\begin{array}{r}-19 \\
26\end{array}$ \\
\hline+3 & $\begin{array}{r}+74 \\
61\end{array}$ & $\begin{array}{r}-58 \\
56\end{array}$ & & $\begin{array}{r}-32 \\
33\end{array}$ & +21 & $\begin{array}{r}+63 \\
58\end{array}$ \\
\hline+4 & $\begin{array}{r}+135 \\
142\end{array}$ & $\begin{array}{r}-206 \\
218\end{array}$ & $\begin{array}{r}-75 \\
72\end{array}$ & $\begin{array}{r}+142 \\
125\end{array}$ & $\begin{array}{r}+110 \\
112\end{array}$ & $\begin{array}{r}-107 \\
89\end{array}$ \\
\hline+5 & $\begin{array}{r}-54 \\
59\end{array}$ & $\begin{array}{r}+53 \\
64\end{array}$ & $\begin{array}{r}+140 \\
145\end{array}$ & $\begin{array}{r}-110 \\
127\end{array}$ & $\begin{array}{r}-63 \\
59\end{array}$ & \\
\hline+6 & $\begin{array}{r}-3 \\
22\end{array}$ & & $\begin{array}{r}-23 \\
26\end{array}$ & $\begin{array}{r}-33 \\
38\end{array}$ & & \\
\hline
\end{tabular}

$k=3$

\begin{tabular}{|c|c|c|c|c|c|c|}
\hline & -2 & -1 & 0 & +1 & +2 & +3 \\
\hline-7 & & $\begin{array}{r}-32 \\
34\end{array}$ & $\begin{array}{r}-119 \\
120\end{array}$ & $\begin{array}{r}+34 \\
39\end{array}$ & & \\
\hline-6 & & $\begin{array}{r}+125 \\
152\end{array}$ & $\begin{array}{r}+256 \\
299\end{array}$ & $\begin{array}{r}-127 \\
144\end{array}$ & $\begin{array}{r}-135 \\
169\end{array}$ & \\
\hline-5 & $\begin{array}{r}-47 \\
49\end{array}$ & $\begin{array}{r}+63 \\
71\end{array}$ & & $\begin{array}{r}-20 \\
24\end{array}$ & $\begin{array}{r}-23 \\
25\end{array}$ & $\begin{array}{r}+25 \\
20\end{array}$ \\
\hline-4 & $\begin{array}{r}-29 \\
32\end{array}$ & $\begin{array}{r}-44 \\
41\end{array}$ & & $\begin{array}{r}+123 \\
128\end{array}$ & $\begin{array}{r}-124 \\
108\end{array}$ & $\begin{array}{r}-11 \\
22\end{array}$ \\
\hline-3 & $\begin{array}{r}+114 \\
115\end{array}$ & & $\begin{array}{r}-76 \\
81\end{array}$ & & $\begin{array}{r}-67 \\
65\end{array}$ & $\begin{array}{r}+77 \\
75\end{array}$ \\
\hline-2 & & $+\begin{array}{r}21 \\
23\end{array}$ & $\begin{array}{r}-138 \\
113\end{array}$ & $\begin{array}{r}-93 \\
100\end{array}$ & $\begin{array}{r}+142 \\
129\end{array}$ & $\begin{array}{r}+68 \\
81\end{array}$ \\
\hline-1 & & & $\begin{array}{r}+91 \\
+55\end{array}$ & $\begin{array}{r}-123 \\
124\end{array}$ & $\begin{array}{r}-37 \\
31\end{array}$ & \\
\hline 0 & & $\begin{array}{r}+134 \\
144\end{array}$ & $\begin{array}{r}+45 \\
39\end{array}$ & $\begin{array}{r}-377 \\
426\end{array}$ & $\begin{array}{r}+27 \\
31\end{array}$ & $\begin{array}{r}+138 \\
144\end{array}$ \\
\hline+1 & & & $\begin{array}{r}-145 \\
123\end{array}$ & $\begin{array}{r}+496 \\
513\end{array}$ & $\begin{array}{r}+158 \\
168\end{array}$ & $\begin{array}{r}-274 \\
298\end{array}$ \\
\hline+2 & & $\begin{array}{r}-174 \\
174\end{array}$ & $\begin{array}{r}-129 \\
134\end{array}$ & $\begin{array}{r}+41 \\
37\end{array}$ & $\begin{array}{r}+63 \\
62\end{array}$ & $\begin{array}{r}-92 \\
72\end{array}$ \\
\hline+3 & & $\begin{array}{r}+204 \\
200\end{array}$ & $\begin{array}{r}-159 \\
156\end{array}$ & $\begin{array}{r}-138 \\
131\end{array}$ & $\begin{array}{r}+69 \\
66\end{array}$ & $\begin{array}{r}+124 \\
132\end{array}$ \\
\hline+4 & $\begin{array}{r}-183 \\
194\end{array}$ & $\begin{array}{r}-51 \\
51\end{array}$ & $\begin{array}{r}158 \\
142\end{array}$ & $\begin{array}{r}+40 \\
46\end{array}$ & $\begin{array}{r}-91 \\
107\end{array}$ & \\
\hline+5 & $\begin{array}{r}-49 \\
60\end{array}$ & $\begin{array}{r}-106 \\
115\end{array}$ & $\begin{array}{r}+168 \\
191\end{array}$ & $\begin{array}{r}+89 \\
100\end{array}$ & $\begin{array}{r}-159 \\
179\end{array}$ & \\
\hline+6 & & $\begin{array}{r}-55 \\
58\end{array}$ & $\begin{array}{r}-43 \\
54\end{array}$ & & & \\
\hline
\end{tabular}

$k=4$

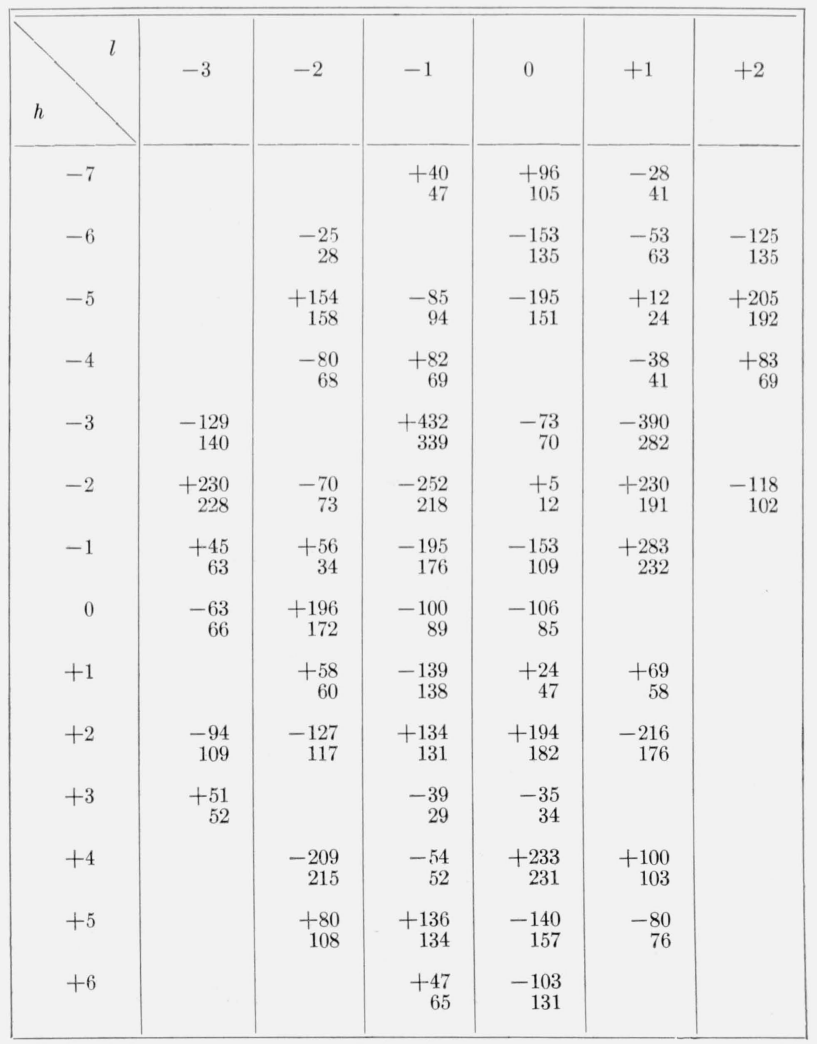


TABLE 3. Calculated and observed structure factors for triclinic $\mathrm{Mg}_{2} \mathrm{~B}_{2} \mathrm{O}_{5}-$ Continued

$l=0$

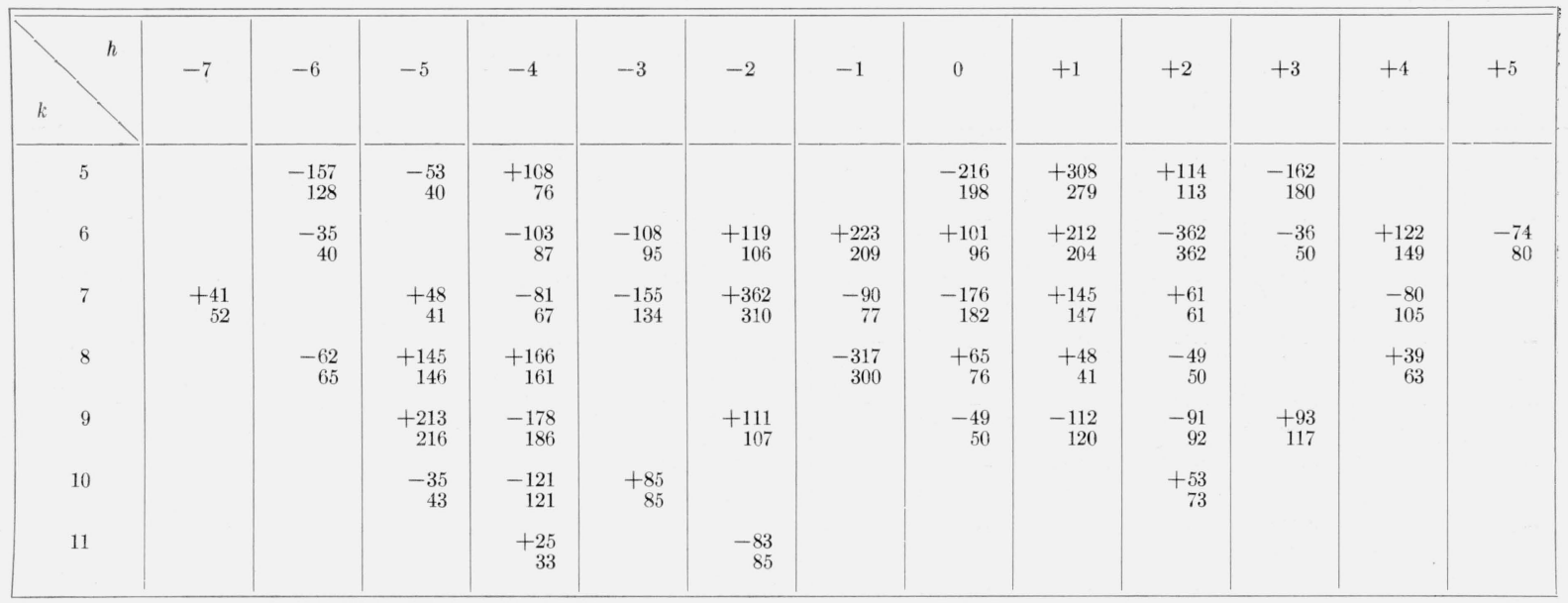

\subsection{Accuracy of Parameters}

Assuming a 15-percent error in the corrected observed intensities and an isotropic coordinate error the average standard deviations of the bond lengths, estimated by the method of Cruickshank [8] are

$$
\begin{aligned}
& \sigma_{\mathrm{B}-\mathrm{O}}=0.018 \mathrm{~A} \\
& \sigma_{\mathrm{O}-\mathrm{O}}=0.011 \mathrm{~A} \\
& \sigma_{\mathrm{Mg}-\mathrm{O}}=0.009 \mathrm{~A} .
\end{aligned}
$$

\section{Description of the Structure}

\subsection{General}

The structure of $\mathrm{Mg}_{2} \mathrm{~B}_{2} \mathrm{O}_{5}$ consists of discrete pyroborate groups and $\mathrm{Mg}^{+2}$ ions. Each magnesium is surrounded octahedrally by six oxygen atoms. Sets of four octahedra are linked by edge sharing and propagated in the direction approximately parallel to (110). These are extended in infinite slats parallel to the $c$ direction by edge sharing with the octahedra in the cells immediately above and below (fig. 3). The pyroborate groupings extend this pattern through $\mathrm{O}_{I V}-\mathrm{B}_{I}-\mathrm{O}_{\mathrm{V}}$ into an extended sheet. The slats of octahedra are also linked normal to the propagation direction by the pyroborate groups. This cross linkage is through $\mathrm{O}_{\mathrm{I}}-\mathrm{B}_{\mathrm{II}}-\mathrm{O}_{\mathrm{II}}$ and $\mathrm{O}_{\mathrm{III}}-\mathrm{B}_{\mathrm{I}}-\mathrm{O}_{\mathrm{IV}}$.

\subsection{Pyroborate Group}

Each boron atom is in triangular coordination with three oxygen atoms. The pyroborate group consists of two such triangles with one shared oxygen (fig. 4). In this coordination type boron should form three coplanar bonds utilizing $\mathrm{sp}^{2}$ hybridization, with interbond angles of $120^{\circ}$. In the $\mathrm{Mg}_{2} \mathrm{~B}_{2} \mathrm{O}_{5}$ structure, the two triangles are not identical. Each has a different environment and nonsymmetric bond lengths. The $\mathrm{O}_{\mathrm{II}}-\mathrm{O}_{\mathrm{IV}}$ distance is shorter than all other edges of the triangles.
This is, however, the only edge of a triangle within the pyroborate group which is shared with an edge of a magnesium octahedron. Within each triangle there are two $\mathrm{B}-\mathrm{O}$ distances averaging $1.39 \mathrm{~A}$ and one somewhat shorter at about $1.36 \mathrm{~A}$. The mean value of all six $\mathrm{B}-\mathrm{O}$ bonds is $1.38_{4}$. Within the $\mathrm{B}_{2} \mathrm{O}_{5}^{-4}$ group. the $\mathrm{B}_{\mathrm{I}}-\mathrm{O}_{\mathrm{IV}}-\mathrm{B}_{\mathrm{II}}$ angle is $134.5^{\circ}$ and the angle between the planes of the triangles is $16^{\circ}$. $B_{I}$ and $B_{I I}$ are within 0.03 and $0.02 \mathrm{~A}$, respectively, of the planes determined by the three coordinated oxygens.

The two outer oxygens in the triangle surrounding $\mathrm{B}_{\mathrm{II}}$ are coordinated as expected to six magnesium atoms while the two peripheral oxygen atoms in the triangle surrounding $B_{I}$ are coordinated to only five magnesium atoms. The center $\mathrm{O}_{\mathrm{IV}}$ is bound to both borons as well as one $\mathrm{Mg}$. $\mathrm{O}_{\mathrm{V}}$ is only bonded to two magnesium atoms, as well as the central boron. All other oxygens are tied to one boron and three magnesiums.

According to Pauling's electrostatic rules the strength of a bond from a cation to an anion is $z / C N$, where $z$ is the charge and $C N$ the coordination number. (This rule is only strictly applicable for equal bond lengths and symmetric geometric arrangements.) Each boron atom is tied to three oxygens; the bond strength is $3 / 3$. Each magnesium is bonded to six oxygens; the bond strength is $2 / 6=1 / 3$. The total charge on the anion must be neutralized in the bonds, or a charge disproportionation occurs. $\mathrm{O}_{I}, \mathrm{O}_{\mathrm{II}}$, and $\mathrm{O}_{\mathrm{III}}$ are each bound to three $\mathrm{Mg}$ and one $\mathrm{B}$ atoms. Thus their charge is neutral. The $\mathrm{O}_{\mathrm{v}}$, bound to two $\mathrm{Mg}$ and one $\mathrm{B}$, has a $-1 / 3$ charge. The $\mathrm{O}_{\mathrm{IV}}$ is tied to both borons as well as one Mg. Thus it has a $+1 / 3$ excess charge, indicating a deviation from Pauling's rule. These bond strengths are based on an equalized distribution. Since the bond lengths vary they represent only an idealized situation. Thus the charge on $\mathrm{O}_{\mathrm{V}}$ is probably equalized by the closer approach of the two Mg atoms. These same $\mathrm{Mg}$ are then bonded rather more loosely to the $\mathrm{O}_{\mathrm{IV}}$ and $\mathrm{O}_{\mathrm{II}}$ atoms. 


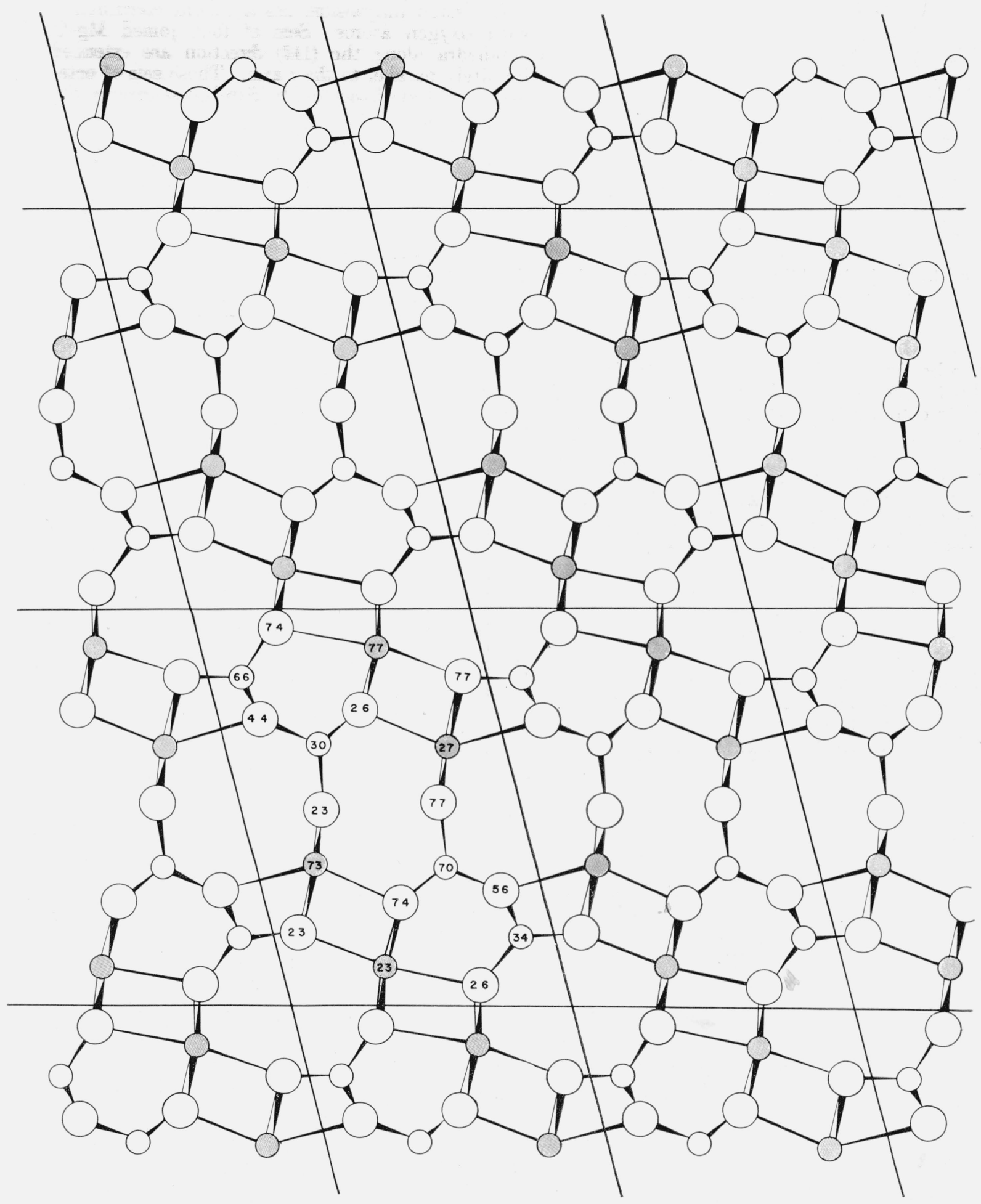

Figure 3. Projection of the structure of $\mathrm{Mg}_{2} \mathrm{~B}_{2} \mathrm{O}_{5}$ on the (001) plane ( $x$ positive to the right, y positive toward the top). Shaded circles are $\mathrm{Mg}$, small circles $\mathrm{B}$, large circles $\mathrm{O}$. The numbers indicate the $z$ parameter. 


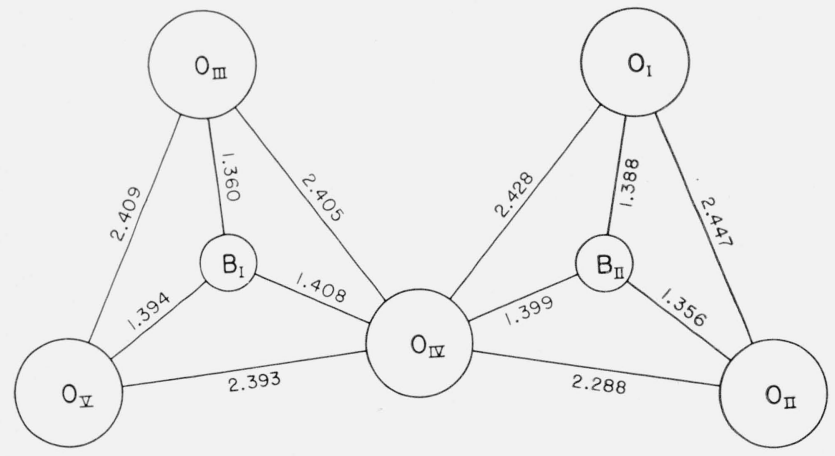

Figure 4. Projection of the pyroborate group showing all interatomic distances in angstrom units.

The best refined borate structure to date appears to be that of orthoboric acid [9]. This structure consists of discrete $\mathrm{BO}_{3}^{-3}$ triangles and the average of all $\mathrm{B}-\mathrm{O}$ bond distances obtained was $1.361 \mathrm{~A}$. This may be compared with the $1.38_{4}$ average oxygen-boron distance obtained for $\mathrm{Mg}_{2} \mathrm{~B}_{2} \mathrm{O}_{5}$ above. The average $\mathrm{O}-\mathrm{O}$ interatomic distance within a $\mathrm{BO}_{3}{ }^{-3}$ triangle for boric acid is $2.356 \mathrm{~A}$, compared to $2.395 \mathrm{~A}$ in the present structure.

\section{Summary}

The triclinic modification of magnesium pyroborate $\mathrm{Mg}_{2} \mathrm{~B}_{2} \mathrm{O}_{5}$ has been shown to be a member of an isostructural series, the other members of which are $\mathrm{Mn}_{2} \mathrm{~B}_{2} \mathrm{O}_{5}, \mathrm{Fe}_{2} \mathrm{~B}_{2} \mathrm{O}_{5}$, and $\mathrm{Co}_{2} \mathrm{~B}_{2} \mathrm{O}_{5}$. The atomic parameters of the $\mathrm{Mg}_{2} \mathrm{~B}_{2} \mathrm{O}_{5}$ have been refined by Fourier and least-squares techniques.
The structure consists of $\mathrm{B}_{2} \mathrm{O}_{5}{ }^{-4}$ groups and $\mathrm{Mg}^{+2}$ ions. Each magnesium has a sixfold coordination with oxygen atoms. Sets of four joined $\mathrm{Mg}-\mathrm{O}$ octahedra along the (110) direction are extended infinitely parallel to the $c$ axis. These sets of octahedra are linked together by pyroborate groups into sheets approximately along (110) with cross linking normal to this direction.

The pyroborate group consists of two joined $\mathrm{BO}_{3}^{-3}$ triangles sharing one corner oxygen. The $\mathrm{B}-\mathrm{O}-\mathrm{B}$ angle is $134.5^{\circ}$ and the boron atoms are in the plane defined by the three surrounding oxygens.

Within the limits of error, all $\mathrm{B}-\mathrm{O}$ distances are equivalent. One side of a triangle is significantly shortened because of edge sharing with a magnesium octahedron.

The authors thank C. T. Ireland for performing some of the earlier computations and Peter O'Hara for aid during the computing procedures. E. M. Levin pointed out the relationship of the phase diagram and correct molecular formula.

\section{References}

[1] ASTM X-ray powder data file cards numbers: 3-0841, 3-0815, 3-0186.

[2] S. V. Berger, Acta Chem. Scand. 4, 1054 (1950).

[3] H. M. Davis and M. A. Knight, J. Am. Ceram. Soc. 28, 100 (1945).

[4] Y. Takeuchi, Acta Cryst. 5, 574 (1952)

[5] C. S. Lu, Rev. Sci. Instr. 14, 331 (1943).

[6] D. Sayre, IBM (personal communication).

[7] V. Vand, The Penna. State Univ. (personal communication).

[8] D. W. J. Cruickshank, Acta Cryst. 2, 65 (1949).

[9] W. H. Zachariasen, Acta Cryst. 7, 305 (1954).

Washington, October 30, 1958. 